\title{
Changes of Ankle Dorsiflexion Using Compression Tissue Flossing: A Systematic Review and Meta-Analysis
}

\author{
Devin S. Kielur and Cameron J. Powden
}

\begin{abstract}
Context: Impaired dorsiflexion range of motion (DFROM) has been established as a predictor of lower-extremity injury. Compression tissue flossing (CTF) may address tissue restrictions associated with impaired DFROM; however, a consensus is yet to support these effects. Objectives: To summarize the available literature regarding CTF on DFROM in physically active individuals. Evidence Acquisition: PubMed and EBSCOhost (CINAHL, MEDLINE, and SPORTDiscus) were searched from 1965 to July 2019 for related articles using combination terms related to CTF and DRFOM. Articles were included if they measured the immediate effects of CTF on DFROM. Methodological quality was assessed using the Physiotherapy Evidence Database scale. The level of evidence was assessed using the Strength of Recommendation Taxonomy. The magnitude of CTF effects from pre-CTF to post-CTF and compared with a control of range of motion activities only were examined using Hedges $g$ effect sizes and 95\% confidence intervals. Randomeffects meta-analysis was performed to synthesize DFROM changes. Evidence Synthesis: A total of 6 studies were included in the analysis. The average Physiotherapy Evidence Database score was $60 \%$ (range $=30 \%-80 \%$ ) with 4 out of 6 studies considered high quality and 2 as low quality. Metaanalysis indicated no DFROM improvements for CTF compared with range of motion activities only (effect size $=0.124$; 95\% confidence interval, -0.137 to $0.384 ; P=.352$ ) and moderate improvements from pre-CTF to post-CTF (effect size $=0.455 ; 95 \%$ confidence interval, 0.022 to $0.889 ; P=.040$ ). Conclusions: There is grade B evidence to suggest CTF may have no effect on DFROM when compared with a control of range of motion activities only and results in moderate improvements from pre-CTF to post-CTF. This suggests that DFROM improvements were most likely due to exercises completed rather than the band application.
\end{abstract}

Keywords: elastic band, intervention, range of motion

Dorsiflexion range of motion (DFROM) is a vital aspect of physical function. Specifically, proper DFROM is an important aspect of one's ability to walk, run, jump, and land. ${ }^{1-5}$ The connection between DFROM and functional aspects may not be strictly due to motion concerns as DFROM has also been linked to muscular impairments at the foot and ankle ${ }^{6}$ as well as proprioception deficits. $3,4,7,8$ Furthermore, the connection between DFROM and injury risk in physically active individuals exemplify the importance of proper DFROM. ${ }^{1}$ Individuals with DFROM deficits are almost 5 times more likely to sustain an ankle sprain. ${ }^{9}$ Acute ankle sprains are associated with short-term disabilities related to pain, range of motion (ROM), strength, and instability. ${ }^{10}$ In addition, ankle sprains are the precursor to chronic ankle instability. ${ }^{11}$ A condition characterized by recurrent episodes of trauma, physical impairments, and deficits in health-related quality of life. ${ }^{11,12}$ Furthermore, those with chronic ankle instability are at an increased risk for long-term health consequences, such as osteoarthritis. ${ }^{11,12}$ Finally, it is important to note that impaired DFROM is a key contributor for many chronic lower-extremity conditions rather than simply a precursor to injury. ${ }^{2,12-15}$ These findings demonstrate the importance of DFROM due to its impact on injury risk, physical function, long-term health, and healthrelated quality of life. Due to these reasons, innovative and novel treatments must be investigated to address the consequences brought on by impaired DFROM.

Kielur is with Indiana State University, Terre Haute, IN, USA. Powden is with the Masters of Science in Athletic Training Program, University of Indianapolis, Indianapolis, IN, USA. Powden (powdenc@uindy.edu) is corresponding author.
Joint mobilization, dynamic stretching, static stretching, instrument assisted soft tissue mobilization, and foam rolling has been independently investigated to target DFROM impairments. ${ }^{7,16-18}$ Each of these interventions has demonstrated promise in improving DFROM, although the literature is mixed for each intervention. In addition, the multitude of intervention strategies may indicate that DFROM deficit could be due to a collection of factors. Thus, research needs to continue to investigate innovative interventions to address DFROM deficits. A newer intervention modality that could address DFROM deficits is compression tissue flossing (CTF). This treatment modality is described as a soft tissue mobilization in which an elastic band is used to add compression to the structures of a joint while the patient actively moves the joint via weight-bearing and or non-weight-bearing activities. ${ }^{19-25}$ Some of the primary clinical effects of this intervention have been proposed as decreased pain, improved patient-reported outcomes, improved ROM, and improved physical abilities, such as jumping and sprinting. ${ }^{19-25}$ While not fully understood, the proposed mechanism of effect is suggested to be due to shearing and mobilization of soft and connective tissue during application. ${ }^{19-25}$ Specifically, at the ankle, CTF has demonstrated signs of efficacy to enhance ROM in healthy, physically active individuals. ${ }^{20-25}$ The literature suggests that CTF may be a valuable intervention to address ROM concerns at the ankle and further investigation to recognize the role this technique may play in soft tissue management is warranted.

The specific application of this technique relies on factors, such as the materials used, the elastic band application, as well as the choice of ROM exercises. ${ }^{19-25}$ Previous investigations have demonstrated improvements in ankle ROM after a single 
application of CTF. ${ }^{19-25}$ However, these investigations have varied in application parameters and outcome measures. This makes it difficult to draw clinical conclusions regarding the effects and application of CTF. Currently, no structured analysis has yet to review the literature and the clinical effectiveness of CTF. A structured review and synthesis of the CTF literature would provide valuable information for clinicians regarding the efficacy of CTF and its application parameters.

\section{Objectives}

The purpose of this systematic review with meta-analysis was to collect, critically appraise, and summarize the available literature regarding $\mathrm{CTF}$ effect on DFROM in physically active individuals.

\section{Evidence Acquisition}

\section{Search Strategy}

A systematic search of the literature was conducted for articles that investigated the effect of CTF on ankle ROM based on the Preferred Reporting Items for Systematic Reviews and MetaAnalyses guidelines. ${ }^{26}$ PubMed and EBSCOhost (CINAHL, MEDLINE, and SPORTDiscus) were searched from 1965 to July 2019 for related articles. A combination of keywords related to CTF and range of motion were combined using Boolean operators to identify potential articles (Table 1). Following the electronic search, a hand search of reference lists was completed.

\section{Selection Criteria}

Articles were first evaluated based on titles and abstracts. If unclear from the title and abstract, the full text was reviewed for inclusion. The following inclusion and exclusion criteria were utilized for determining study eligibility:

\section{Inclusion Criteria.}

- Experimental designs, such as randomized control trials, randomized trials, crossover, counterbalanced, or cohort.

- Examined the immediate effects of CTF intervention or equivalent.
- Included physically active participants.

- Included outcomes of ROM at the ankle.

\section{Exclusion Criteria.}

- Did not report measures of central tendency or variability to allow for calculation of Hedges $g$ effect size (ES).

- Articles that were case studies, guidelines reviews, or abstracts.

- Articles not published in English.

- Articles that evaluated CTF in combination with another intervention.

\section{Methodological Quality}

The authors (D.S.K. with 3 y of athletic training experience; C.J.P. with $9 \mathrm{y}$ of athletic training experience) independently reviewed each article using the Physiotherapy Evidence Database (PEDro) scale. The PEDro scale is a validated outcome tool for assessing the methodological quality of clinical trials. ${ }^{27}$ Articles were evaluated based on study characteristics, randomization, and data reporting. ${ }^{27}$ Results were then categorized and studies were considered high quality $(\geq 60 \%)$ or low quality $(\leq 60 \%){ }^{27}$ If criteria within the articles were conflicted between the reviews, a discussion occurred and a consensus was made to determine the final score.

\section{Data Extraction}

Articles were reviewed by the investigators to identify investigation design, sample size, participant demographics, technique application, exercise prescription, ROM outcomes, measurement timeline, and results. Data interpretations were critically compared between the investigators for agreement. The use of an independent reviewer (M.J.R. with 4 y of experience) was used to resolve any discrepancies in interpretation.

The primary outcome for this systematic review was DFROM. Means, SDs, and numbers of participants were extracted and grouped based on comparison. Data were categorized as either CTF versus a control of ROM activities without CTF band application (ROM activities) or pre-CTF versus post-CTF comparisons.

\section{Data Analysis and Synthesis}

Separate summary meta-analyses were performed for each comparison (CTF vs ROM activities, pre-CTF vs post-CTF) to examine

\section{Table 1 Search Strategy}

\begin{tabular}{|c|c|c|c|c|}
\hline Step & Search terms & Boolean operator & EBSCOhost & PubMed \\
\hline 1 & $\begin{array}{l}\text { Tack floss } \\
\text { Compression tissue flossing } \\
\text { VooDoo floss bands } \\
\text { RockFloss } \\
\text { Floss bands } \\
\text { Mobility bands }\end{array}$ & OR & 2596 & 2158 \\
\hline 2 & $\begin{array}{l}\text { Range of motion } \\
\text { Flexibility }\end{array}$ & OR & 344,963 & 150,319 \\
\hline 3 & 1,2 & AND & 23 & 151 \\
\hline Duplicates & & & & $4^{*}$ \\
\hline Total identified & & & & 6 \\
\hline
\end{tabular}

*Total number of duplicates between EBSCO and PubMed. 
DFROM effects. For summary analyses, multiple point estimates from the same study were pooled to reduce sample size inflation. Each meta-analysis was completed by using random effects models to pool individual point estimates from the included studies using bias-corrected Hedges $g$ ES and 95\% confidence intervals (CIs) to determine the magnitude of effect. Positive ESs indicated greater levels of DFROM in the CTF group compared with the ROM activities group and at post-CTF compared with pre-CTF. All metaanalysis procedures were completed in Comprehensive MetaAnalysis software (version 3.3.070; Biostat Inc, Englewood, NJ). The authors interpreted ESs as weak $(\leq 0.40)$, moderate (0.41-0.69), or strong $(\geq 0.70){ }^{28}$ The alpha level was set a priori at .05 . To further examine the data, the authors performed a qualitative assessment of ESs and CIs by assessing the differences in ES estimates between groups and determining whether the CIs crossed 0.

\section{Sensitivity Analysis}

The effect of quality criteria on the assumptions of level of evidence for high-quality studies $(\geq 60 \%)$ was tested by subjecting the criteria to changes of $\pm 10 \%$ and determining the subsequent level of evidence change. In addition, a one-study removed analysis was completed to examine the influence of a single participant group on the observed summary effect of each summary analysis. This method explores the effect of removing single participant groups from the overall summary to observe changes in the summary effect.

\section{Level of Evidence and Grade of Recommendation}

Using the Strength of Recommendation Taxonomy, each study was categorized and graded based on evidence provided on a classification level of 1,2 , or $3 .{ }^{29}$ A level 1 ranking indicates the study provided good-quality patient-oriented evidence (PEDro score $\geq$ $60 \%$ ) that further validates clinical applicability through highquality randomized control trials and cohort studies; level 2 indicates limited quality patient-oriented evidence $(<60 \%$ PEDro score) with lower-quality clinical trials and case studies; level 3 rankings indicate empirical, disease-oriented, case studies. ${ }^{29}$ Graded assessments were then based on the following criteria: grade A with consistent, good-quality patient-oriented evidence; grade $\mathrm{B}$, inconsistent, or limited quality patient-oriented evidence; or grade $\mathrm{C}$, a consensus, opinion, disease-oriented outcome. ${ }^{29}$

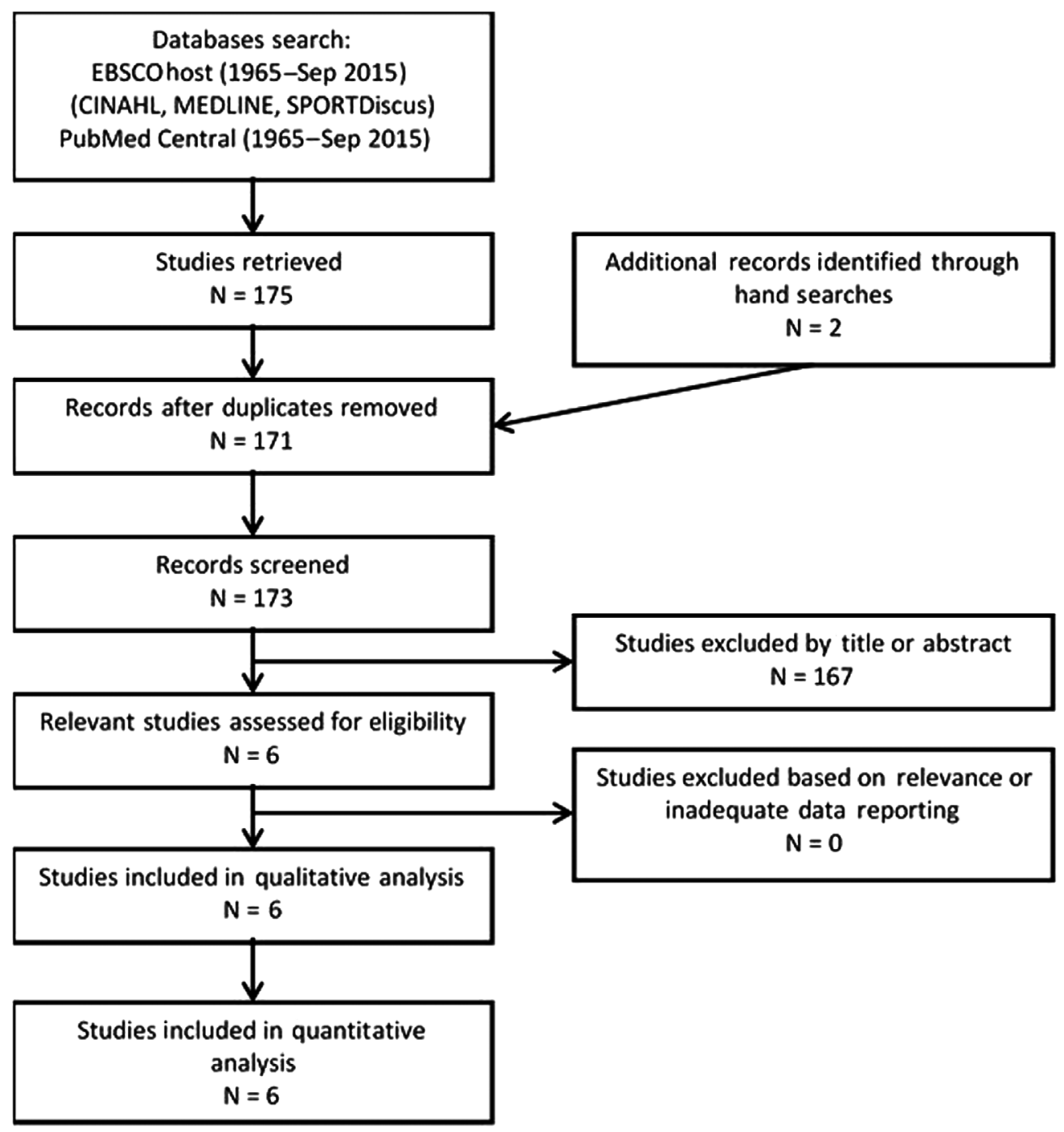

Figure 1 - Compression tissue flossing search results. 


\section{Evidence Synthesis}

\section{Literature Search}

A total of 175 studies were identified through the initial electronic search (Figure 1). Four duplicates were removed and 2 were added after a hand search of references. Of the 173 identified articles, 167 were removed based on the relevance of the title or abstract summary. A total of 6 articles were identified and included for qualitative and quantitative review (Table 2). ${ }^{20-25}$ All 6 articles evaluated pre-CTF versus post-CTF outcomes, ${ }^{20-25}$ and 5 articles evaluated CTF versus ROM activities measurements. ${ }^{20,22-25}$ ROM was measured using the weight-bearing lunge test in all 6 studies $^{20-25}$ and 3 used goniometric measurements..$^{20,23,25}$

\section{Study Characteristics}

Participants in 5 of the investigations were physically active recreational athletes ${ }^{20-23,25}$ and one included professional male rugby players. $^{24}$ All studies included healthy participants free from lower-extremity injury at the time of collection. ${ }^{20-25}$ Three studies had participants act as their own ROM activities group comparison, ${ }^{20,23,24} 2$ studies had separate ROM activities groups, ${ }^{22,25}$ and one study did not report CTF versus ROM activities outcomes. ${ }^{21}$

A variety of CTF bands were used throughout the included studies. Three studies used VooDoo floss bands, ${ }^{21,23,25} 2$ used Life floss bands, ${ }^{20,22}$ and one study did not specify its materials. ${ }^{24}$ In total, 5 studies applied the band with variable resistance following a standard ankle bandaging technique, ${ }^{20,22-25}$ one study applied the band starting at the distal end of the Achilles, moving up the calf with variable resistance. ${ }^{21}$ The amount of applied pressure was classified in 3 studies from 178 (18) up to 182 (38) $\mathrm{mm} \mathrm{Hg},{ }^{20,22,23} 2$ studies did not specify the amount of compression applied, ${ }^{24,25}$ and one study applied approximately a $70 \%$ to $75 \%$ pull of the band. ${ }^{21}$ Various activities were completed during the application of the CTF band. A total of 3 studies utilized ankle weight-bearing range of motion and stretching activities in isolation, ${ }^{21,24,25} 2$ studies performed an active non-weightbearing range of motion at the ankle, ${ }^{20,22}$ and one study combined non-weight-bearing active range of motion at the ankle with a series of ankle weight-bearing range of motion activities. ${ }^{23}$ In addition, ROM activity groups completed activities that matched their corresponding CTF group but without the application of a band.

All 6 studies collected ankle DFROM outcomes. ${ }^{20-25}$ The weight-bearing lunge test was measured in all 6 studies, ${ }^{20-25}$ but only one study assessed straight leg and bent leg weight-bearing lunge. ${ }^{23}$ Additional range of motion assessments were conducted by 3 studies using goniometric, ${ }^{20,23,25}$ and one study used an overhead squat test. ${ }^{25} \mathrm{~A}$ summary of the conclusions are provided in Table 2 which further outlines the study designs and implementation of CTF.

\section{Methodologic Quality}

A quality design assessment was conducted by the research team and is highlighted in Table 3. The 2 independent reviewers agreed on all 66 items on the PEDro scale. Differences between both assessors were discussed and concluded on for a final summary. The average PEDro score between all studies was $60 \%$ with a range of scores between $30 \%$ and $80 \%$. We found four level 1 studies 20,22,23,25 and two level 2 studies. ${ }^{21,25}$ For all 6 studies that reviewed pre-CTF to post-CTF, the average PEDro score was $63 \% .^{20-25}$ The 5 studies that investigated CTF versus ROM activities results, the average PEDro score was $66 \% .^{20,22-25}$

\section{Data Synthesis}

Pooled ES and summary effects are presented in Figures 2 and 3. For the CTF versus ROM activities comparison, there was a weak summary effect for CTF creating miniscule improves of DFROM $(\mathrm{ES}=0.124 ; 95 \% \mathrm{CI},-0.137$ to 0.384$)$ that was not significant $(P=.352)$. For the pre-CTF to post-CTF comparison, there was a moderate summary effect for CTF improving measures of DFROM $(\mathrm{ES}=0.455 ; 95 \% \mathrm{CI}, 0.022$ to 0.889$)$ that was significant $(P=.040)$.

\section{Sensitivity Analysis}

When the standard for methodological quality was increased by $10 \%$ (70\%), there was a change from 4 high-quality studies $20,22,23,25$ to 3 high-quality studies. ${ }^{20,23,25}$ When the standard was decreased by $10 \%(50 \%)$, there was a change from 4 high-quality studies ${ }^{20,22,23,25}$ to 5 high-quality studies. ${ }^{20,22-25}$ The results of our sensitivity analysis found that the studies included in this review were of generally high quality.

The one-study removed analysis for CTF versus ROM activities demonstrated that the summary ES remained weak and ranged from 0.012 to 0.208 (95\% CI, -0.297 to 0.522$)$. There were no significant removals $(P>.196)$ indicating that no single participant group meaningfully influenced the CTF versus ROM activities summary effect. The one-study removed analysis for pre-CTF to post-CTF demonstrated that the summary ES varied as it ranged from 0.285 to $0.547(95 \% \mathrm{CI},-0.127$ to 1.050$)$. There were 2 significant removals, Driller et $\mathrm{al}^{22}(P=.022)$ and Mills et $\mathrm{al}^{24}$ $(P=.043)$ indicating that these participant groups meaningfully influenced the summary effect. When Driller et $\mathrm{al}^{22}$ was removed, the summary effect increased to 0.547 and the CI narrowed $(95 \%$ CI, 0.080 to 1.013). In addition, when Mills et $\mathrm{al}^{24}$ was removed, the summary effect increased to 0.518 and the CI narrowed $(95 \%$ CI, 0.016 to 1.019). Finally, while not significant, the removal of Stevenson et $\mathrm{al}^{23}(P=.54)$ reduced the summary ES to a weak level $(\mathrm{ES}=0.285)$ and the narrowest CI $(95 \% \mathrm{CI},-0.005$ to 0.575$)$. While the removal of Stevenson et $\mathrm{al}^{23}$ was not significant, the substantial narrowing of the $95 \%$ CI and the largest change in summary effect suggests that it most likely had a large impact on the summary estimate.

\section{Level of Evidence and Strength of Recommendation}

This review indicates there is grade $\mathrm{B}$ evidence that CTF produces no effects on DFROM when compared with a control group of ROM activities only based on a trivial ES that was not significant. In addition, grade $\mathrm{B}$ evidence suggested that $\mathrm{CTF}$ may result in moderate DFROM improvements immediately following application when assessed using pre-CTF to post-CTF data. However, these pre-CTF to post-CTF improvements are most likely due to the ROM activities completed with CTF, as there were no CTF versus ROM activities differences. In addition, the results of the one-study removed analysis caution that pre-CTF to post-CTF effects may be inflated based on the results of one study. Overall, these recommendations are based on findings from four level 1 investigation$\mathrm{s}^{20,22,23,25}$ and two level 2 investigations. ${ }^{21,24}$

\section{Discussion}

The purpose of this systematic review with meta-analysis was to collect, critically appraise, and summarize the available literature 
Table 2 Study Design and Implementation

\begin{tabular}{|c|c|c|c|c|c|c|}
\hline $\begin{array}{l}\text { Author and } \\
\text { design }\end{array}$ & $\begin{array}{l}\text { Sample } \\
\text { size/group }\end{array}$ & Inclusion & Band and application & Intervention & Outcomes & Conclusion \\
\hline $\begin{array}{l}\text { Driller and } \\
\text { Overmayer } \\
\text { Crossover }\end{array}$ & $\begin{array}{l}52 \text { recrea- } \\
\text { tional } \\
\text { athletes } \\
29 \text { males } \\
23 \text { females } \\
\text { Acted as } \\
\text { own control }\end{array}$ & $\begin{array}{l}\text { Participate in exer- } \\
\text { cise }>3 \text { times a } \\
\text { week; free from } \\
\text { lower limb injury. }\end{array}$ & $\begin{array}{l}\text { Life floss bands applied at } \\
182(38) \mathrm{mm} \mathrm{Hg} \text {. } \\
\text { Wrapped from mid foot to } \\
\text { above malleoli, overlap- } \\
\text { ping by } 50 \%, 3 \text { figure } 8 \mathrm{~s} \text {. }\end{array}$ & $\begin{array}{l}\text { CTF: } 20 \text { reps of } \\
\text { seated PFROM and } \\
\text { DFROM } \\
\text { CON: } 20 \text { reps of } \\
\text { seated PFROM and } \\
\text { DFROM }\end{array}$ & $\begin{array}{l}\text { ROM: } \\
\text { WBLT; } \\
\text { DFROM; } \\
\text { PFROM } \\
\text { Other out- } \\
\text { comes: Sin- } \\
\text { gle-leg verti- } \\
\text { cal jump }\end{array}$ & $\begin{array}{l}\text { Significant pre-WBLT to } \\
\text { post-WBLT improve- } \\
\text { ments as well as pre to } \\
\text { post decrease in gonio- } \\
\text { metric DFROM for the } \\
\text { CTF group. } \\
\text { No significant differences } \\
\text { between groups for } \\
\text { WBLT or DFROM. }\end{array}$ \\
\hline $\begin{array}{l}\text { Driller et al }{ }^{22} \\
\text { Parallel group }\end{array}$ & $\begin{array}{l}69 \text { recrea- } \\
\text { tional } \\
\text { athletes } \\
32 \text { males } \\
37 \text { females } \\
\text { Floss: } 38 \\
\text { CON: } 31\end{array}$ & $\begin{array}{l}\text { Participate in exer- } \\
\text { cise }>3 \text { times a } \\
\text { week; free from } \\
\text { lower limb injury. }\end{array}$ & $\begin{array}{l}\text { Life floss band applied at } \\
178(18) \mathrm{mm} \mathrm{Hg} \\
\text { Wrapped from mid foot to } \\
\text { above malleoli, overlap- } \\
\text { ping by } 50 \%, 3 \text { figure } 8 \mathrm{~s} \text {. }\end{array}$ & $\begin{array}{l}\text { CTF: Active ROM } \\
2 \text { min } \\
\text { CON: Active ROM } \\
2 \text { min }\end{array}$ & $\begin{array}{l}\text { ROM: } \\
\text { WBLT } \\
\text { Other out- } \\
\text { comes: CMJ, } \\
\text { sprint test } \\
\text { (5-15 m), } \\
\text { Kikuhime } \\
\text { pressure }\end{array}$ & $\begin{array}{l}\text { Significant improvements } \\
\text { to WBLT after the appli- } \\
\text { cation of CTF for up to } \\
45 \mathrm{~min} \text {. }\end{array}$ \\
\hline $\begin{array}{l}\text { Stevenson } \\
\text { et } \mathrm{al}^{23} \\
\text { Crossover }\end{array}$ & $\begin{array}{l}5 \text { male rec- } \\
\text { reational } \\
\text { athletes } \\
\text { Acted as } \\
\text { own control }\end{array}$ & $\begin{array}{l}\text { Convenience sam- } \\
\text { ple; reported tight- } \\
\text { ness, stiffness, heel } \\
\text { pain, Achilles ten- } \\
\text { don pain, or calf } \\
\text { pain. }\end{array}$ & $\begin{array}{l}\text { VooDoo floss applied at } \\
180 \mathrm{~mm} \mathrm{Hg} \text { starting at the } \\
\text { mid foot and compressing } \\
\text { up to the inferior soleus. } \\
180 \mathrm{~mm} \mathrm{Hg} \text { tightness. }\end{array}$ & $\begin{array}{l}\text { CTF: } 2 \text { min of } \\
\text { activity: non- } \\
\text { weight-bearing } \\
\text { DFROM, PFROM, } \\
\text { and circumduc- } \\
\text { tion } \times 20 \\
10 \text { body aquats } \\
15 \text { eccentric heel } \\
\text { raises. } \\
\text { CON: } 2 \text { min of } \\
\text { activity: non- } \\
\text { weight-bearing } \\
\text { DFROM, PFROM, } \\
\text { and circumduc- } \\
\text { tion } \times 20 \\
10 \text { body squats } \\
15 \text { eccentric heel } \\
\text { raises. }\end{array}$ & $\begin{array}{l}\text { ROM: } \\
\text { DFROM; } \\
\text { PFROM; } \\
\text { straight leg } \\
\text { WBLT; bent } \\
\text { leg WBLT } \\
\text { Other out- } \\
\text { comes: per- } \\
\text { ceived } \\
\text { tightness }\end{array}$ & $\begin{array}{l}\text { Significant increase in } \\
\text { DFROM following CTF } \\
\text { application. }\end{array}$ \\
\hline $\begin{array}{l}\text { Ross and } \\
\text { Kandassamy } \\
\text { Crossover }\end{array}$ & $\begin{array}{l}10 \text { partici- } \\
\text { pants } \\
5 \text { males } \\
5 \text { females }\end{array}$ & $\begin{array}{l}\text { Free from lower } \\
\text { limb injury for } \\
3 \mathrm{mo},<10 \mathrm{~cm} \\
\text { WBLT. }\end{array}$ & $\begin{array}{l}\text { VooDoo band was applied } \\
\text { at } 70 \%-75 \% \text { tension at } \\
\text { inferior end of the Achilles } \\
\text { with } 50 \% \text { overlap toward } \\
\text { the muscle belly. }\end{array}$ & $\begin{array}{l}\text { CTF: Deep squat- } \\
\text { ting and heel } \\
\text { raise } \times 150 \mathrm{~s} \\
\text { CON: Deep squat- } \\
\text { ting and heel } \\
\text { raise } \times 150 \mathrm{~s}\end{array}$ & $\begin{array}{l}\text { ROM: } \\
\text { WBLT }\end{array}$ & $\begin{array}{l}\text { Small to moderate } \\
\text { DFROM improvements } \\
\text { were found after CTF was } \\
\text { applied immediate and } 7 \mathrm{~h} \\
\text { after application. }\end{array}$ \\
\hline $\begin{array}{l}\text { Mills et al }{ }^{24} \\
\text { Counterbalance } \\
\text { crossover }\end{array}$ & $\begin{array}{l}14 \text { male } \\
\text { professional } \\
\text { rugby } \\
\text { athletes } \\
\text { Acted as } \\
\text { own control }\end{array}$ & $\begin{array}{l}\text { Free from lower- } \\
\text { extremity injury. }\end{array}$ & $\begin{array}{l}\text { Floss band; } \\
\text { applied using a standard } \\
\text { ankle bandaging tech- } \\
\text { nique. } \\
\text { Tightness not specified. }\end{array}$ & $\begin{array}{l}\text { CTF: Active } \\
\text { PFROM and } \\
\text { DFROM } \\
2 \text { min } \\
\text { CON: Active } \\
\text { PFROM and } \\
\text { DFROM } \\
2 \text { min }\end{array}$ & $\begin{array}{l}\text { ROM: } \\
\text { WBLT } \\
\text { Other out- } \\
\text { comes: CMJ, } \\
\text { sprint test } \\
(5-20 \mathrm{~m})\end{array}$ & $\begin{array}{l}\text { No significant improve- } \\
\text { ment between CTF and } \\
\text { CON groups during } \\
\text { WBLT assessment. }\end{array}$ \\
\hline $\begin{array}{l}\text { Hagen et } \mathrm{al}^{25} \\
\text { Randomized- } \\
\text { single blind }\end{array}$ & $\begin{array}{l}32 \text { physi- } \\
\text { cally active } \\
\text { individuals } \\
20 \text { males } \\
12 \text { females } \\
\text { CTF: } 8 \\
\text { Dynamic: } 8 \\
\text { Static: } 8 \\
\text { CON: } 8\end{array}$ & $\begin{array}{l}18-50 \text { y old, free of } \\
\text { pain. }\end{array}$ & $\begin{array}{l}\text { Rogue VooDoo floss; } \\
\text { applied using a standard } \\
\text { ankle bandaging technique } \\
\text { with medial and lateral heel } \\
\text { locks and figure "8" wrap. } \\
\text { Tightness not specified. }\end{array}$ & $\begin{array}{l}\text { CTF: } 2 \times \text { bent knee } \\
\text { lunge with } 1-2 \mathrm{~s} \\
\text { hold } \times 20 \\
\text { Dynamic: } 2 \times \text { bent } \\
\text { knee lunge with } \\
1-2 \mathrm{~s} \text { hold } \times 20 \\
\text { Static: } 45 \mathrm{~s} \text { bent } \\
\text { knee lunge } \times 2 \\
\text { CON: } 10 \mathrm{~min} \\
\text { seated rest }\end{array}$ & $\begin{array}{l}\text { ROM: } \\
\text { PFROM; } \\
\text { WBLT } \\
\text { Other out- } \\
\text { comes: over- } \\
\text { head squat } \\
\text { test }\end{array}$ & $\begin{array}{l}\text { Significant DFROM im- } \\
\text { provements were made } \\
\text { using CTF and dynamic } \\
\text { stretch routine. }\end{array}$ \\
\hline
\end{tabular}

Abbreviations: CMJ, countermovement jump test; CON, control; CTF, compression tissue flossing; DFROM, dorsiflexion range of motion; PFROM, plantar flexion range of motion; reps, repetitions; ROM, range of motion; WBLT, weight-bearing lunge test. 
Table 3 PEDro Results

\begin{tabular}{|c|c|c|c|c|c|c|}
\hline PEDro criteria & $\begin{array}{c}\text { Driller and } \\
\text { Overmayer }^{20}\end{array}$ & $\begin{array}{l}\text { Driller } \\
\text { et } a^{22}\end{array}$ & $\begin{array}{l}\text { Stevenson } \\
\text { et } \mathrm{al}^{23}\end{array}$ & $\begin{array}{c}\text { Ross and } \\
\text { Kandassamy }^{21}\end{array}$ & $\begin{array}{l}\text { Mills } \\
\text { et } \text { al }^{24}\end{array}$ & $\begin{array}{l}\text { Hagen } \\
\text { et } \mathrm{al}^{25}\end{array}$ \\
\hline (1) Random allocated & $\mathrm{x}$ & $\mathrm{x}$ & $\mathrm{x}$ & No & Unknown & $\mathrm{x}$ \\
\hline (2) Allocation concealed & $\mathrm{x}$ & Unknown & $\mathrm{x}$ & Unknown & Unknown & $\mathrm{x}$ \\
\hline (3) Similar at baseline & $\mathrm{x}$ & $\mathrm{x}$ & $\mathrm{x}$ & No & $\mathrm{x}$ & $\mathrm{x}$ \\
\hline (4) Blinding of all subjects & No & No & No & No & No & No \\
\hline (5) Blinding of all therapists & Unknown & Unknown & Unknown & Unknown & Unknown & No \\
\hline (6) Blinding of all assessors & Unknown & Unknown & Unknown & Unknown & Unknown & $\mathrm{x}$ \\
\hline (7) More than $85 \%$ of subjects & $\mathrm{x}$ & $\mathrm{x}$ & $\mathrm{x}$ & $\mathrm{x}$ & $\mathrm{x}$ & $\mathrm{x}$ \\
\hline (8) Intention to treat & $\mathrm{x}$ & $\mathrm{x}$ & $\mathrm{x}$ & $\mathrm{x}$ & $\mathrm{x}$ & $\mathrm{x}$ \\
\hline $\begin{array}{l}\text { (9) Between-groups statistical } \\
\text { comparison }\end{array}$ & $\mathrm{x}$ & $\mathrm{x}$ & $\mathrm{x}$ & No & $\mathrm{x}$ & $\mathrm{x}$ \\
\hline (10) Point measures and variability & $\mathrm{x}$ & $\mathrm{x}$ & $\mathrm{x}$ & $\mathrm{x}$ & $\mathrm{x}$ & $\mathrm{x}$ \\
\hline $\begin{array}{l}\text { (11) Eligibility criteria (not } \\
\text { included) }\end{array}$ & $\mathrm{x}$ & $\mathrm{x}$ & $\mathrm{x}$ & $\mathrm{x}$ & $\mathrm{x}$ & $\mathrm{x}$ \\
\hline \multirow[t]{2}{*}{ Total } & 7 & 6 & 7 & 3 & 5 & 8 \\
\hline & 0.70 & 0.60 & 0.70 & 0.30 & 0.50 & 0.80 \\
\hline
\end{tabular}

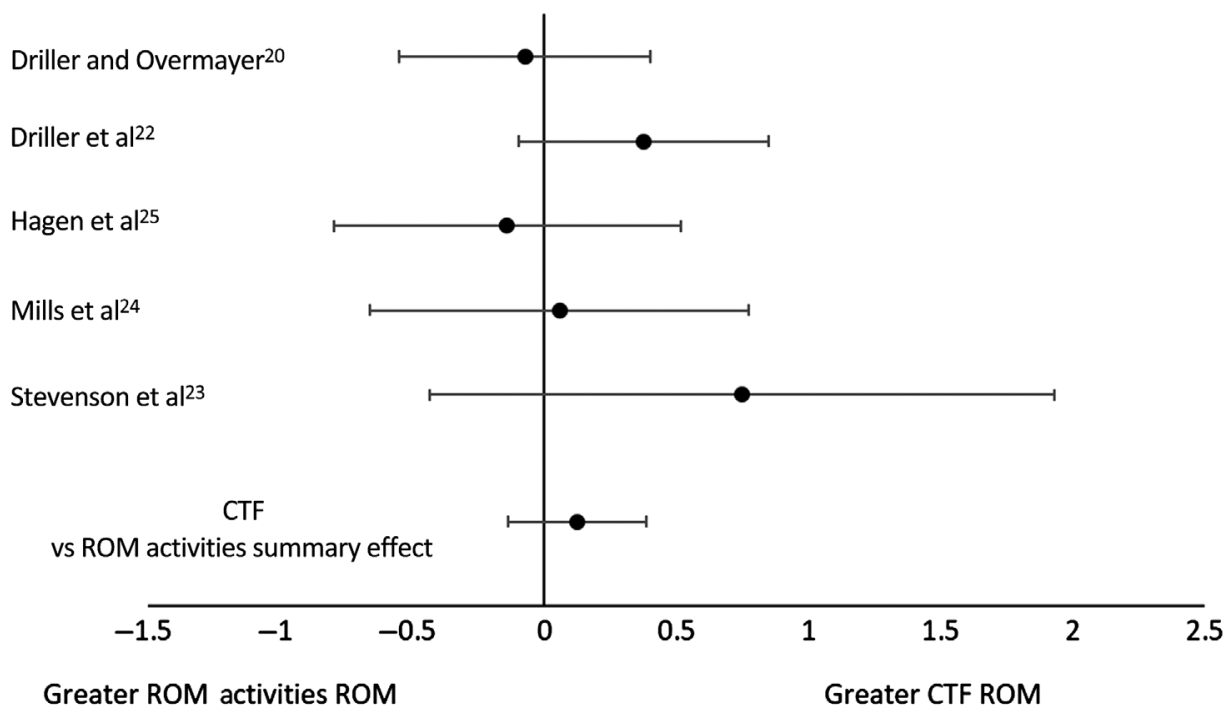

Figure 2 - Forest plot of Hedges $g$ effects sizes and 95\% confidence intervals for precomparisons versus postcomparisons. CTF indicates compression tissue flossing; ROM, range of motion.

regarding the effect of CTF on DFROM in physically active individuals. The results of this investigation indicate that there is grade B evidence that when CTF was compared with control intervention of ROM activities, no DFROM changes were identified. Pre-CTF to post-CTF comparisons indicated there may be moderate improvements from baseline with the use of the included CTF protocols that included band application and ROM activities. These 2 findings in combination indicate that there is most likely little to no effect on DFROM with CTF and that improvements are presumably due to the exercises completed during the CTF band application. In addition, further caution should be had with the preintervention to postintervention analysis as the one-study removed analysis indicated that one study ${ }^{23}$ could be inflating the summary effect. These recommendations are based on level 1 and level 2 literature.
This review's main finding was that the application of CTF had no effect on DFROM in physically active individuals compared with a control group of ROM activities. While there is limited research regarding CTF's mechanism of effect, it has been theorized that ROM changes may occur due to: pain relief via a gate control mechanism, ${ }^{30}$ fascial shearing, ${ }^{30}$ and blood flow disruption. ${ }^{31}$ It is unlikely that a gate control mechanism was triggered via the compression of the band and subsequent stimulation of mechanoreceptors within the included studies as all participants were healthy in nature. Fascial shearing is thought to create ROM increases by restoring proper fascial gliding by releasing fascial adhesions with the deformation caused by the combination of the band's compressive forces and the movement from therapeutic exercises. ${ }^{30}$ Again, with included participants being healthy in 


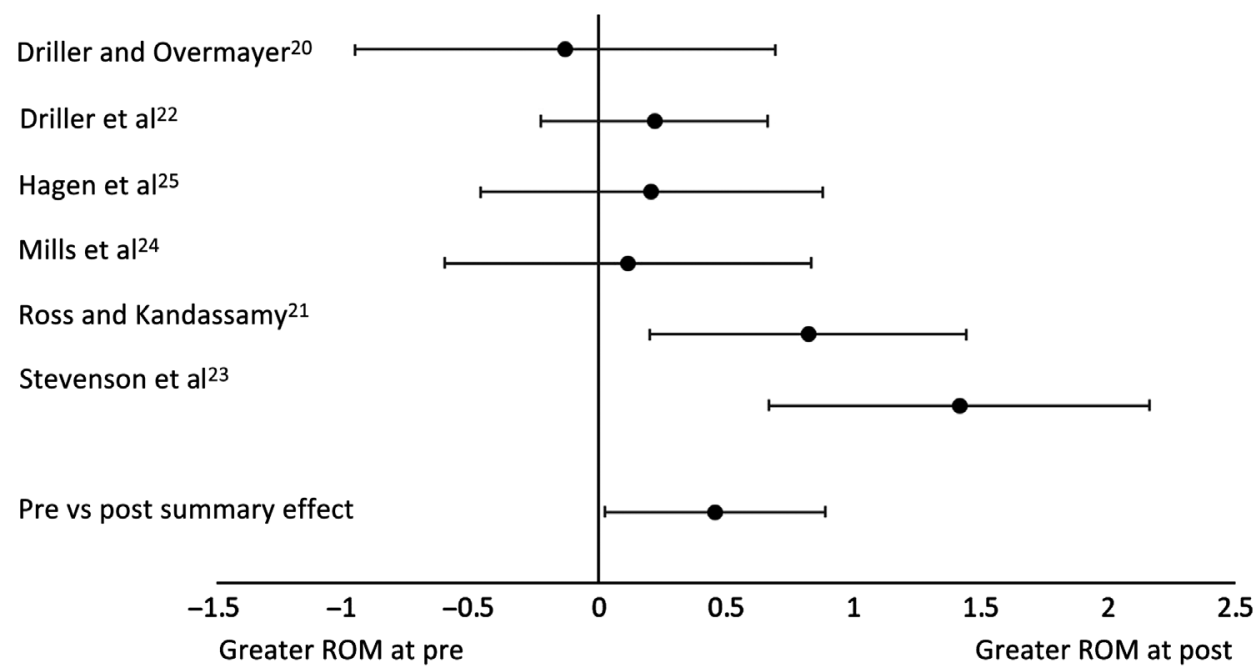

Figure 3 - Forest plot of Hedges $g$ effects sizes and 95\% confidence intervals for control and intervention comparisons. ROM indicates range of motion.

nature, there may be limited fascial adhesions to be released. Finally, blood flow disruption is thought to jumpstart hormonal and catecholamine responses that could result in enhanced blood flow and muscle nutrition that improve ROM. ${ }^{31}$ It is plausible that due to the cascade of biological events that must occur during this mechanism that it may not result in immediate ROM effects. The previously mentioned theories are speculative in nature and are meant to help guide future CTF flossing research but may provide some rationale for our findings.

While the ROM activities group comparison indicated there were not changes in DFROM due to CTF intervention, the pre-CTF to post-CTF analysis found that there were moderate DFROM improvements. These findings in combination may indicate that DFROM improvements may be due to items similar between CTF and control groups of ROM activities protocols. Primarily, the included studies' comparison groups completed the same tasks as the CTF intervention groups, with the difference being no application of the CTF band. Activities completed varied from non-weightbearing active range of motion to weight-bearing activities, such as weight-bearing lunges, eccentric heel raises, and/or squatting. Again, since there were no significant CTF versus ROM activities differences, similar effect sizes, and the same activities were performed between both groups, range of motion improvements are more likely to have been the result of the ROM activities completed. This is further suggested as the previous literature indicates that DFROM can be improved via the previously mentioned therapeutic exercises. ${ }^{32}$ Finally, improvements to DFROM are most likely due to the combination of weight-bearing and non-weight-bearing activities completed during CTF protocols.

Although the meta-analysis indicated moderate DFROM improvements from pre-CTF to post-CTF, caution is warranted as two large $\mathrm{ESs}^{21,23}$ may have skewed the summary effect. Stevenson et $\mathrm{a}^{23}$ had the largest $\mathrm{ES}(\mathrm{ES}=1.416)$ and only included 5 participants. Due to the lack of participants within this investigation, the study is at risk of bias and influence from extremes. This limits the generalizability of the results. It is also important to note that Stevenson et $\mathrm{al}^{23}$ was the only investigation to include nonweight-bearing and weight-bearing activity with functional movement and eccentric loading at the posterior ankle. Eccentric loading has previously been identified as an effective intervention to improve lower-extremity flexibility and joint range of motion. ${ }^{33}$ Thus, the contribution of CTFs to DFROM improvements from preintervention to postintervention is doubtful.

\section{Clinical Implication}

This review demonstrated that the application of CTF in combination with movement may result in weak to moderate DFROM improvements in healthy, physically active individuals immediately following application. Regardless of variable application techniques, materials, and exercise combinations, CTF in combination with ROM activities is a possible option to target soft tissue restrictions in the ankle. However, based on the results of this metaanalysis, the use of the band most likely does not add to the improvement of ROM. For future research and clinical exploration, the most promising effects may be achieved with band placement starting at the midfoot and wrapping to the inferior soleus. ${ }^{20,22-25}$ In addition, the completion of around 2 minutes of activity that includes non-weight-bearing dorsiflexion, plantar flexion, and circumduction movements in addition to weight-bearing activity, such as body squats or eccentric heel raise, seems to be most promising. ${ }^{23}$ These recommendations are based on the identified studies that demonstrated the greatest improvements in their investigations and do not support any gold standard of care.

Furthermore, the included literature investigated outcomes beyond ROM that may warrant clinical application. CTF participants saw immediate improvements during timed distance runs, vertical jump, and jumping velocity in which some effects lasted up to 45 minutes after CTF application..$^{20,22,24}$ In addition, the use of CTF improved healthy individuals overhead squat quality immediately and up to 12 minutes post application. ${ }^{25}$ These findings, in combination, indicate that CTF may have promise as a performance enhancing modality. However, continued and consistent research is needed into this claim. Finally, none of the included studies investigated CTF in a pathologic population. A recent case report ${ }^{34}$ provides low-level evidence to indicate that CTF may be a useful modality to reduce pain and improve function in individuals with chronic Achilles tendonitis who do not respond to traditional 
rehabilitation. Further investigation into CTF's usefulness with pathologic patients is needed at this time.

Caution should be taken when deciding to implement CTF due to the potential for vascular occlusion. Studies included in this review applied CTF with between 160 and $220 \mathrm{~mm} \mathrm{Hg} .^{20,22,23}$ Complete arterial occlusion has been recorded around 168.4 (14.5) and 173.3 (15.6) $\mathrm{mm} \mathrm{Hg.}{ }^{35}$ Based on these numbers, there is a strong likelihood that the investigated CTF protocols within this review resulted in partial to complete occlusion of the ankle vasculature. While considered a safe therapeutic intervention when properly monitored and applied, prolonged occlusion has resulted in physical deformities, such as rhabdomyolysis. ${ }^{36-38}$

\section{Future Research and Limitations}

Studies included in this review were limited to the ankle and healthy physically active populations. An absence of diverse populations, variety of patient demographics, and body regions inhibit a consensus for application beyond the ankle and into pathologic populations. The absence of long-term effects also inhibits the understanding of the length of treatment with successful clinical improvements. Future investigations should aim to collect similar outcomes to establish consistency as well as patient-oriented outcomes for short-term or long-term success.

\section{Conclusions}

This synthesis and meta-analysis suggest that CTF has no effect on DFROM when compared with control groups of ROM activities. Moderate DFROM improvements were identified with pre-CTF to post-CTF comparisons. In combination, these findings indicate that caution should be taken when attributing pre-CTF to post-CTF DFROM improvements to CTF as improvements were most likely due to exercises completed during CTF. Evaluations of DFROM changes were limited to the immediate effect of a single treatment. The studies included in this review included healthy and physically active individuals. As such, the effects of CTF on DFROM in pathologic populations and after multiple interventions are unclear at this time. Larger sample sizes, prolonged timeline assessments, patient-oriented outcomes, and additional control interventions should be investigated to further understand the clinical utility of CTF.

\section{Acknowledgments}

This research did not receive any specific grant from funding agencies in the public, commercial, or not-for-profit sectors. The authors acknowledge the contributions of Matthew J. Rivera as an independent reviewer on the project.

\section{References}

1. Mason-Mackay AR, Whatman C, Reid D. The effect of reduced ankle dorsiflexion on lower extremity mechanics during landing: a systematic review. J Sci Med Sport. 2017;20(5): 451-458. PubMed ID: 26117159 doi:10.1016/j.jsams.2015.06.006

2. Hoch MC, Farwell KE, Gaven SL, Weinhandl JT. Weight-bearing dorsiflexion range of motion and landing biomechanics in individuals with chronic ankle instability. J Athl Train. 2015;50(8):833-839. PubMed ID: 26067428 doi:10.4085/1062-6050-50.5.07
3. Terada M, Harkey M, Wells AM, Pietrosimone BG, Gribble PA. The influence of ankle dorsiflexion and self-reported patient outcomes on dynamic postural control in participants with chronic ankle instability. Gait Posture. 2014;40(1):193-197. PubMed ID: 24768526 doi:10.1016/j.gaitpost.2014.03.186

4. Plisky PJ, Rauh MJ, Kaminski TW, Underwood FB. Star excursion balance test as a predictor of lower extremity injury in high school basketball players. J Orthop Sports Phys Ther. 2006;36(12):911-919. PubMed ID: 17193868 doi:10.2519/jospt.2006.2244

5. Powden CJ, Hoch J, Hoch JM. Reliability and minimal detectable change of the weight-bearing lunge test: a systematic review. Man Ther. 2015;20(4):524-532. PubMed ID: 25704110 doi:10.1016/j .math.2015.01.004

6. Gullen-Rogel P, San Emeterio C, Marin PJ. Associations between ankle dorsiflexion range of motion and foot and ankle strength in young adults. J Phys Ther Sci. 2017;29:1336-1367.

7. Vallandingham RA, Gaven SL, Powden CJ. Changes in dorsiflexion and dynamic postural control after mobilizations in individuals with chronic ankle instability: a systematic review and meta-analysis. $J$ Athl Train. 2019;54(4):403-417. PubMed ID: 30870009 doi:10. 4085/1062-6050-380-17

8. Merdon S, Klusendorf A, Kernozek T. Influence of injury on dynamic postural control in runners. Int J Sports Phys. 2016:11(4):366-377.

9. Pope R, Herbert R, Kirwan J. Effects of ankle dorsiflexion range and pre-exercise calf muscle stretching on injury risk in Army recruits. Aust J Physiother. 1998;44(3):165-172. PubMed ID: 11676730 doi:10.1016/S0004-9514(14)60376-7

10. van Rijn RM, van Os AG, Bernsen RM, Luijsterburg PA, Koes BW, Bierma-Zeinstra SM. What is the clinical course of acute ankle sprains? A systematic literature review. Am J Med. 2008;121(4):324-331.e7. PubMed ID: 18374692 doi:10.1016/j.amjmed.2007.11.018

11. Gribble PA, Bleakley CM, Caulfield BM, et al. 2016 consensus statement of the international ankle consortium: prevalence, impact and long-term consequences of lateral ankle sprains. Br J Sports Med. 2016;50(24):1493-1495. doi:10.1136/bjsports-2016-096188

12. Hertel J, Corbett RO. An updated model of chronic ankle instability. $J$ Athl Train. 2019;54(6):572-588. PubMed ID: 31162943 doi:10. 4085/1062-6050-344-18

13. Rabin A, Kozol Z, Finestone AS. Limited ankle dorsiflexion increases the risk for mid-portion Achilles tendinopathy in infantry recruits: a prospective cohort study. J Foot Ankle Res. 2014;7(48):1-7.

14. Lima YL, Ferreira VMLM, de Paula Lima PO, Bezerra MA, de Oliveira RR, Almeida GPL. The association of ankle dorsiflexion range of motion and dynamic knee valgus: a systematic review and meta-analysis. Phys Ther Sport. 2018;29:61-69. PubMed ID: 28974358 doi:10.1016/j.ptsp.2017.07.003

15. Simpson JD, Stewart EM, Turner AJ, Macias DM, Chander H, Knight AC. Lower limb joint kinetics during a side-cutting task in participants with or without chronic ankle instability. J Athl Train. 2020; 55(2):169-175. PubMed ID: 31895591 doi:10.4085/1062-6050334-18

16. Mederios DM, Martini TF. Chronic effect of different types of stretching on ankle dorsiflexion range of motion: systematic review and meta-analysis. Foot. 2018;34:28-35.

17. Ikeda N, Otsuka S, Kawanishi Y, Kawakami Y. Effects of instrumentassisted soft tissue mobilization on musculoskeletal properties. Med Sci Sports Exerc. 2019;51(10):2166-2172. PubMed ID: 31083046 doi:10.1249/MSS.0000000000002035

18. Kelly S, Veardsley C. Specific and cross-over effects of foam rolling on ankle dorsiflexion range of motion. Int J Sports Phys. 2016; 11(4):544-551. 
19. Starrett K, Cordoza G. Becoming a Supple Leopard. The Ultimate Guide to Resolving Pain, Preventing Injury, and Optimizing Athletic Performance. Las Vegas, NV: Victory Belt Publishing Inc.; 2013.

20. Driller MW, Overmayer RG. The effects of tissue flossing on ankle range of motion and jump performance. Phys Ther Sport. 2017; 25:20-24. PubMed ID: 28254581 doi:10.1016/j.ptsp.2016.12.004

21. Ross S, Kandassamy G. The effects of 'Tack and Floss' active joint mobilization on ankle dorsiflexion range of motion using voodoo floss bands. J Phys Ther. 2017.

22. Driller MW, Mackay K, Mills B, Tavares F. The effects of tissue flossing on ankle range of motion, jump and sprint performance: a follow up study. Phy Ther Sport. 2017;28:29-33. doi:10.1016/j.ptsp. 2017.08.081

23. Stevenson PJ, Stevenson RK, Duarte KW. Acute effects of the voodoo flossing band on ankle range of motion. J Med Biomed Appl Sci. 2019:7(6);244-253.

24. Mills B, Mayo B, Tavares F, Driller M. The effect of tissue flossing on ankle range of motion, jump, and sprint performance in elite rugby union athletes [published online ahead of print June 12, 2019]. J Sport Rehabil. PubMed ID: 30676229 doi:10.1123/jsr.2018-0302

25. Hagen N, Reyes C, Liu EK. Can compression assist with ankle movement preparation? A comparison of static, dynamic, and dynamic with compression stretching on ankle dorsiflexion motion. J Aust Strength Cond. 2017;25(4):6-17.

26. Moher D, Liberati A, Tetzlaff J, Altman DG, Group P. Preferred reporting items for systematic reviews and meta-analyses: the PRISMA statement. PLoS Med. 2009;6(7):e1000097. PubMed ID: 19621072 doi:10.1371/journal.pmed.1000097

27. Morton NA. The PEDro scale is a valid measure of the methodological quality of clinical trials: a demographic study. Aust J Physiother. 2009;55(2):129-133. PubMed ID: 19463084 doi:10.1016/S00049514(09)70043-1

28. Cohen J. Statistical Power Analysis for the Behavioral Sciences. 2nd ed. Hillsdale, NJ: Lawrence Erlbaum Associates; 1988.

29. Ebell MH, Siwek J, Weiss BD, et al. Strength of recommendation taxonomy (SORT): a patient-centered approach to grading evidence in the medical literature. J Am Board Fam Pract. 2004;17(1):59-67. PubMed ID: 15014055 doi:10.3122/jabfm.17.1.59

30. Stecco A, Gesi M, Stecco C, Stern R. Fascial components of the myofascial pain syndrome. Curr Pain Headache Rep. 2013;17(8): 352. PubMed ID: 23801005 doi:10.1007/s11916-013-0352-9

31. Reeves GV, Kraemer RR, Hollander DB, et al. Comparison of hormone responses following light resistance exercise with partial vascular occlusion and moderately difficult resistance exercise without occlusion. J Appl Physiol. 2006;101(6):1616-1622. PubMed ID: 16902061 doi:10.1152/japplphysiol.00440.2006

32. Young R, Nix S, Wholohan A, Bradhurst R, Reed L. Interventions for increasing ankle joint dorsiflexion: a systematic review and metaanalysis. J Foot Ankle Res. 2013;6(1):46. PubMed ID: 24225348 doi:10.1186/1757-1146-6-46

33. O'Sullivan K, McAuliffe S, DeBurca N. The effects of eccentric training on lower limb flexibility: a systematic review. Br J Sports Med. 2012;46(12):833-834.

34. Borda J, Selhorst M. The use of compression tack and flossing along with lacrosse ball massage to treat chronic Achilles tendinopathy in an adolescent athlete: a case report. J Man Manipul Ther. 2017; 25(1):57-61. doi:10.1080/10669817.2016.1159403

35. Tuncali B, Boya H, Kayhan Z, Araç Ş, Çamurdan MA. Clinical utilization of arterial occlusion pressure estimation method in lower limb surgery: effectiveness of tourniquet pressures. Acta Orthop Traumatol Turc. 2016;50(2):171-1770. PubMed ID: 26969952

36. Loenneke JP, Wilson JM, Wilson GJ, Pujol TJ, Bemben MG. Potential safety issues with blood flow restriction training. Scand $J$ Med Sci Sports. 2011;21(4):510-518. PubMed ID: 21410544 doi:10. 1111/j.1600-0838.2010.01290.x

37. Iversen E, Røstad V. Low-load ischemic exercise-induced rhabdomyolysis. Clin J Sports Med. 2010;20(3):218-219. doi:10.1097/JSM. 0b013e3181df8d10

38. Tabata S, Suzuki Y, Azuma K, Matsumoto H. Rhabdomyolysis after performing blood flow restriction training. J Strength Cond Res. 2016;30(7):2064-2068. PubMed ID: 26677831 doi:10.1519/JSC. 0000000000001295 